(2) OPEN ACCESS

\title{
Evidence of cushioning of tobacco tax increases in large retailers in Australia
}

\author{
Megan Bayly 이, ${ }^{1}$ Michelle Scollo 주, ${ }^{1,2}$ Melanie A Wakefield (i) ${ }^{1}$
}

${ }^{1}$ Centre for Behavioural Research in Cancer, Cancer Council Victoria, Melbourne, Victoria, Australia

${ }^{2}$ Prevention Division, Cancer Council Victoria, Melbourne, Victoria, Australia

\section{Correspondence to}

Megan Bayly, Centre for Behavioural Research in Cancer, Cancer Council Victoria, Melbourne, Victoria, Australia; megan.bayly@cancervic.org.au

Received 24 November 2020 Revised 15 March 2021 Accepted 18 March 2021
D Check for updates

(C) Author(s) (or their employer(s)) 2021. Re-use permitted under CC BY-NC. No commercial re-use. See rights and permissions. Published by BMJ.

To cite: Bayly M, Scollo M, Wakefield MA. Tob Control Epub ahead of print: [please include Day Month Year]. doi:10.1136/

tobaccocontrol-2020-056385

\section{ABSTRACT}

Background Tobacco companies may attempt to minimise the impact of tobacco tax increases on consumers by gradually passing on the price rise over several months. This study examined whether there was evidence of large Australian tobacco retailers engaging in this practice (known as cushioning) over a period including both routine indexation and large annual tobacco excise increases.

Methods Advertised prices of nine factory-made cigarette (FMC) and nine roll-your-own tobacco (RYO) products were recorded from two stores monthly from December 2016 to December 2019. Per cent change in price from the previous month was analysed for FMC and RYO products, controlling for year, month, tobacco company and supermarket chain.

Results Significant main effects of month were observed for FMC and RYO products (both $p<0.001$ ). Large, significant average increases in per cent change in price were observed in September for FMC (6.51\%) and RYO (11.45\%) products, the month of the annual excise increase and prices also significantly increased in October (FMC: $3.01 \%$; RYO: 1.91\%). Significant increases were also observed in the months after the March annual routine indexation: by $1.10 \%$ in May for FMC products and by $1.09 \%$ in April for RYO products.

Conclusion This study has demonstrated evidence of cushioning of tax increases of FMC and RYO products in large Australian supermarkets. The monthly per cent change in price significantly increased several months after routine excise indexation and in the 2 months following a large annual excise increase. Further research with a larger sample of products and stores is needed to confirm these findings.

\section{BACKGROUND}

Tobacco taxation is a fundamental tobacco control policy, ${ }^{1}$ with extensive evidence of increases in tobacco prices reducing demand among both adults and youth. ${ }^{2}$ Taxes on tobacco in Australia include excise duty (or excise-equivalent customs duty) on every cigarette and on each gram of smoking tobacco and a $10 \%$ goods and services tax. ${ }^{3}$ Tobacco excise is indexed twice yearly in Australia-in March and September, in line with changes in national average weekly earnings. Additional $12.5 \%$ increases in excise duty have been applied each year since 2013. ${ }^{3}$ From 2017, further increases to the excise duty on loose tobacco were implemented to reduce the gap in taxation between factory-made cigarettes (FMCs) and cigarettes made from roll-your-own tobacco (RYO). ${ }^{4}$ Excise comprises approximately $65 \%$, and Goods and Services Tax (GST) a further
$9.1 \%$, of the sale price of the leading brand of cigarettes in Australia. ${ }^{3}$

The Australian tobacco market is highly differentiated in terms of price segments, pack sizes and multipack configurations, offering a confusing range of price points and volume discounting. ${ }^{5}$ These pricing strategies make it difficult for consumers to compare prices per stick or gram and the relative change in price of different products. Even after a tax increase, less expensive options are almost always available for smokers-either a product that is cheaper per stick or gram or a smaller product that costs less upfront. ${ }^{7-9}$ Supermarkets are the largest purchase channel in Australia. ${ }^{10}$ Tobacco products in supermarkets are usually sold below recommended retail price with prices fluctuating across the year. ${ }^{1112}$

Sudden 'shock' price increases are thought to have a greater effect on reducing consumption than increases that are gradually introduced. ${ }^{13}$ In other countries such as the UK, tobacco companies have engaged in strategies apparently designed to minimise the impact of tax increases by gradually passing them on to consumers. ${ }^{13-15}$ By adding a small proportion of the price increase over several months before and/or after the tax increase, rather than all at once on the date on which the tax increase comes into effect, they 'cushion' the effect of the tax increase on the consumer.

This study aimed to explore the extent of cushioning in the Australian tobacco market in a major retail channel over a period of large tax increases. Between January 2017 and December 2019, tobacco excise increased in Australia on six occasions. A small increase (indexation only) occurred on 1 March of each of the 3 years, in line with the change in average weekly earnings over the previous 6 months. A much larger increase occurred on 1 September each year reflecting not just indexation but also the legislated $12.5 \%$ annual increases and the additional increase in the excise duty on RYO tobacco. Average increases were approximately $1.4 \%$ in March. September increases averaged $13.8 \%$ for FMC products and $17.6 \%$ for RYO products. ${ }^{16}$ Recommended retail prices (RRPs) of the products monitored in this study, where published by Australia's retail tobacco traders association, ${ }^{17}$ increased over the study period by $2.1 \%$ and $1.7 \%$ on average in March for FMC and RYO products, respectively. Increases in RRPs in September averaged 9.0\% for FMC products and $15.3 \%$ for RYO products. As excise is only a component of the final retail price, total price increases would be expected to be less in percentage terms than that of the excise 
increase, if manufacturer and retail margins were maintained in dollar terms.

\section{METHODS}

From December 2016 to December 2019, we conducted monthly checks of the advertised prices of sentinel tobacco products in an outlet of each of the two largest Australian supermarket chains, located in low socioeconomic status suburbs in Melbourne. We recorded the price of nine FMC and nine RYO products in both supermarkets from brands popular among Australian smokers or prominently promoted within stores. ${ }^{18}$ Prices were recorded in the third week of each month to ensure any intended changes associated with the excise increases at the start of the month had been implemented by the stores. The same brands and pack/ pouch sizes were recorded in each month. Three FMC and three RYO products from each of the three major tobacco companies operating in Australia were selected, including one product from each main market segment from each company: budget, mainstream and premium. The selected products were Benson \& Hedges 20s, Bond Street 25s, Horizon 50s, JPS 25s, Marlboro $25 \mathrm{~s}$, Peter Jackson 30s, Peter Stuyvesant 20s, Rothmans 25s, Winfield 25s, Choice $25 \mathrm{~g}$, Craftsman $25 \mathrm{~g}$, Drum $50 \mathrm{~g}$, JPS 25 g, Longbeach 55 g, Port Royal 25 g, Rothmans 20 g, White Ox $25 \mathrm{~g}$ and Winfield $50 \mathrm{~g}$.

Of a potential 1332 observations (two tobacco types $\times$ three companies $\times$ three market segments $\times$ two supermarkets in each of 37 months), 1268 pack prices were able to be recorded (monthly minimum=31, maximum $=36$ ). Prices from at least one supermarket were available for each of the products for all months other than January-April 2017 (one RYO product missing) and November and December 2019 (one RYO product missing).

\section{Analysis}

Per cent change in pack price from the previous month was the unit of analysis, calculated for 1237 observations from January 2017 to December 2019. Products were coded by tobacco type, supermarket chain and tobacco company, and month and year identifier variables were created. Linear regression analysis was performed to examine differences in per cent change in pack price by month, controlling for year, tobacco company and supermarket chain. An initial model showed a significant interaction between month and tobacco type $(F(111209)=5.00$, $\mathrm{p}<0.001)$; therefore, the analysis was stratified by tobacco type. August was used as the reference month, having the smallest average price change for FMC and RYO products. Tests of main effects of categorical variables (month and tobacco company) were performed, and adjusted average per cent changes in pack prices were produced for each month using the margins command. Analysis was undertaken in Stata/MP V.14.2.

\section{RESULTS}

Table 1 shows significant main effects of month on per cent change in advertised pack price for both FMC and RYO products. Compared with August - the month with the least change in price-September and October showed significant increases in average FMC and RYO prices.

The adjusted marginal means show distinct patterns of price changes across months. For FMC products, while average prices increased by almost 1\% in March and April, only the 1.1\% price increase in May was significant. For RYO products, a significant increase in average price of $1.1 \%$ was seen in April, but again the average March increase was not significant.
September and October average price increases were significant for FMC and RYO products. The October FMC price increase $(3.0 \%)$ was almost half that of the September increase $(6.5 \%)$. For RYO products, the per cent increase was much larger in September (11.5\%) compared with October (1.9\%), and almost twice that of FMC products in the same month. Given the large change that occurred in September, the October per cent increases would be larger in real terms (in dollar value) than if the same per cent change was seen after any other month.

The average per cent change in price was negative in June for both FMC and RYO, although these changes were small and did not reach significance.

\section{DISCUSSION}

Consistent with research in the UK, this study demonstrated evidence in Australia of the tobacco industry strategically incrementing prices over time when passing on to consumers the cost of tobacco excise increases, with prices continuing to increase at least 1 month after the scheduled change.

During the period after scheduled routine indexation on 1 March, RYO products increased most in April, while FMC products increased most in May after similar but non-significant increases also occurred in the preceding 2 months. In addition to cushioning, this suggests overshifting: tobacco companies increased their prices beyond what would be required to cover the cost of the average March excise adjustment, particularly for FMC products. Overshifting of tax increases (which may occur on products generally used by less price-sensitive smokers) is a concern for public health policy on tobacco because it enables companies to more dramatically underprice other products used by price-sensitive smokers. It also enables companies to secure additional resources for promotional purposes such as lobbying and any other allowable form of marketing (for instance providing incentives or price discounts for bulk purchases by retailers). ${ }^{19}$

Cushioning was also observed in the month directly after the large September adjustments. Most of the price increase was introduced in September: this increase is often publicised, ${ }^{20}$ so smokers-particularly RYO smokers-would expect prices to increase substantially in that month. However, prices continued to increase by a smaller but still substantial margin in October. Again, the average per cent increase in the month following the scheduled excise increase was larger for FMC products suggesting that more of the increase is delayed for FMC products.

Cushioning is not the only strategy by which the impact of tax increases can be mitigated. It is likely that both retailers and consumers purchase as many tobacco products as practicable ahead of each preannounced tax increase. Governments could increase the effectiveness of tax increases by requiring wholesalers to limit wholesale sales quantities in months ahead of such increases to no more than the average of previous months. The effect of tax increases can also be mitigated through the introduction of new, lower priced products; once again governments could mitigate such effects through the adoption of minimum pricing policies.

It may be that certain types of products are cushioned more than others. There are highly differentiated price segments among FMC brands, ${ }^{5}$ and the prices of budget brands targeted at price-sensitive smokers may be increased more gradually than those of premium products. A larger sample of products would be required to test this possibility.

Discounting of FMC and RYO products in June was suggested by negative average per cent changes in price. These discounts may be intended to provide price incentives to smokers to purchase more or continue smoking in the lead-up to tax large increases 
Table 1 Differences in monthly per cent change in advertised pack price by tobacco type across 2017-2019, regression coefficients and adjusted marginal means

\begin{tabular}{|c|c|c|c|c|c|c|}
\hline & \multicolumn{3}{|c|}{$\begin{array}{l}\text { Factory-made cigarettes } \\
(n=641)\end{array}$} & \multicolumn{3}{|c|}{$\begin{array}{l}\text { Roll-your-own tobacco } \\
(n=596)\end{array}$} \\
\hline & Coefficient & $95 \% \mathrm{Cl}$ & $P$ value & Coefficient & $95 \% \mathrm{Cl}$ & $P$ value \\
\hline Year & 0.26 & $(-0.11$ to 0.64$)$ & 0.164 & 0.29 & $(-0.03$ to 0.62$)$ & 0.077 \\
\hline Month & \multicolumn{3}{|c|}{$F(11625)=13.55, p<0.001$} & \multicolumn{3}{|c|}{$F(11580)=51.75, p<0.001$} \\
\hline January & -0.55 & $(-2.04$ to 0.94$)$ & 0.467 & -0.27 & $(-1.54$ to 1.00$)$ & 0.672 \\
\hline February & 0.53 & $(-0.95$ to 2.02$)$ & 0.480 & -0.17 & $(-1.45$ to 1.10$)$ & 0.788 \\
\hline March* & 0.94 & $(-0.54$ to 2.42$)$ & 0.214 & 0.41 & $(-0.86$ to 1.68$)$ & 0.530 \\
\hline April & 0.98 & ( -0.51 to 2.47$)$ & 0.196 & 0.73 & $(-0.54$ to 2.00$)$ & 0.259 \\
\hline May & 1.09 & $(-0.40$ to 2.58$)$ & 0.152 & -0.58 & $(-1.85$ to 0.69$)$ & 0.372 \\
\hline June & -0.70 & $(-2.18$ to 0.78$)$ & 0.354 & -1.19 & $(-2.47$ to 0.10$)$ & 0.070 \\
\hline July & 0.21 & $(-1.27$ to 1.69$)$ & 0.781 & -0.54 & $(-1.81$ to 0.73$)$ & 0.400 \\
\hline August (ref) & 1.00 & & & 1.00 & & \\
\hline September* & 6.50 & (5.01 to 7.99 ) & 0.000 & 11.10 & (9.83 to 12.36$)$ & 0.000 \\
\hline October & 2.99 & (1.50 to 4.48$)$ & 0.000 & 1.56 & (0.29 to 2.83 ) & 0.016 \\
\hline November & 0.34 & $(-1.15$ to 1.83$)$ & 0.653 & 0.08 & $(-1.20$ to 1.35$)$ & 0.907 \\
\hline December & -0.18 & $(-1.67$ to 1.31$)$ & 0.811 & -0.58 & $(-1.87$ to 0.72$)$ & 0.382 \\
\hline Company & \multicolumn{3}{|c|}{$F(2625)=0.03, p=0.966$} & \multicolumn{3}{|c|}{$F(2580)=0.37, p=0.690$} \\
\hline BATA (ref) & 1.00 & & & 1.00 & & \\
\hline IT & 0.07 & ( -0.67 to 0.82$)$ & 0.846 & 0.15 & $(-0.49$ to 0.79$)$ & 0.655 \\
\hline PM & -0.02 & $(-0.77$ to 0.72$)$ & 0.954 & 0.29 & $(-0.37$ to 0.95$)$ & 0.389 \\
\hline Supermarket & 0.13 & ( -0.48 to 0.74$)$ & 0.667 & -0.17 & $(-0.07$ to 0.35$)$ & 0.519 \\
\hline \multicolumn{7}{|c|}{ Adjusted marginal means } \\
\hline & Per cent & $95 \% \mathrm{Cl}$ & $P$ value & Per cent & $95 \% \mathrm{Cl}$ & $P$ value \\
\hline January & -0.54 & $(-1.60$ to 0.52$)$ & 0.315 & 0.08 & $(-0.82$ to 0.99$)$ & 0.857 \\
\hline February & 0.54 & $(-0.50$ to 1.59$)$ & 0.308 & 0.18 & $(-0.73$ to 1.10$)$ & 0.695 \\
\hline March & 0.95 & $(-0.10$ to 2.00$)$ & 0.075 & 0.76 & $(-0.14$ to 1.67$)$ & 0.098 \\
\hline April & 0.99 & $(-0.07$ to 2.05$)$ & 0.066 & 1.09 & (0.18 to 1.99$)$ & 0.019 \\
\hline May & 1.10 & (0.04 to 2.16$)$ & 0.042 & -0.22 & (-1.13 to 0.69$)$ & 0.634 \\
\hline June & -0.69 & $(-1.74$ to 0.36$)$ & 0.197 & -0.83 & $(-1.75$ to 0.10$)$ & 0.079 \\
\hline July & 0.22 & $(-0.83$ to 1.27$)$ & 0.679 & -0.19 & $(-1.09$ to 0.72$)$ & 0.685 \\
\hline August & 0.01 & (-1.04 to 1.06$)$ & 0.983 & 0.36 & $(-0.53$ to 1.25$)$ & 0.430 \\
\hline September & 6.51 & (5.45 to 7.57 ) & 0.000 & 11.45 & (10.56 to 12.35 ) & 0.000 \\
\hline October & 3.01 & (1.95 to 4.06$)$ & 0.000 & 1.91 & (1.01 to 2.82 ) & 0.000 \\
\hline November & 0.35 & ( -0.71 to 1.41$)$ & 0.513 & 0.43 & $(-0.48$ to 1.35$)$ & 0.353 \\
\hline December & -0.17 & $(-1.23$ to 0.89$)$ & 0.752 & -0.22 & $(-1.15$ to 0.72$)$ & 0.647 \\
\hline
\end{tabular}

* Scheduled indexation increases occur on 1 March and 1 September of each year; additional 12.5\% excise increases occurred on 1 September of each year. BATA, British American Tobacco Australia; IT, Imperial Tobacco; PM, Philip Morris.

when they may otherwise start to consider quitting. Alternatively, it could be a sales strategy related to the end of the Australian financial year on 30 June. These observed patterns were small and need to be confirmed in analysis of prices for a larger number of observations.

The current data are limited to supermarkets in one major city. We cannot be sure whether cushioning of price increases would similarly occur in other retail channels, whether this is initiated by tobacco companies or retailers and whether there might be systematic differences in the extent of cushioning across areas with differing levels of household income. However, supermarkets comprise the largest retail channel for tobacco purchases in Australia, and we found no significant effects of supermarket chain or tobacco company, indicating cushioning is likely a widely employed strategy. The sample primarily included long-standing products, to avoid the confounding effects of discounting of newly introduced and discontinued items. These brands are among the most widely used according to small consumer surveys from several years ago ${ }^{18}$; however, no data on brand share by sales are publicly available in Australia.

A larger national study to monitor a wider range of products across multiple retail channels is needed to examine the complex pricing strategies that may be employed by the tobacco industry. A more efficient solution would be to require the disclosure of sales and prices data by tobacco companies as is done in countries such as New Zealand. ${ }^{21} 22$

Cushioning may be more likely in a situation such as in Australia where tax increases have been announced ahead of time. However, even tax increases announced immediately before implementation can be cushioned by applying increases over two or more subsequent months. Taxation of tobacco products in Australia would be much more effective in encouraging smokers to quit if prices were only allowed to change twice each year, within a specified number of days of the excise duty increasing each March and September. A licence system applied to the retailing of tobacco products could establish such practice as a condition. A further condition could 
prohibit both undershifting or overshifting of tax increases. A licence or registration number applied to every retailer would also allow the collection and compilation of data on products, prices and sales and evaluation of the effectiveness of tobacco control interventions at a local, regional and national level.

\section{What this paper adds}

- The tobacco industry employs pricing strategies to minimise the impact of tobacco tax increases on consumers and to confuse price signals. These strategies include the gradual passing on of tax increases, known as cushioning.

- As yet, no studies have demonstrated the presence of cushioning in Australia, a market with large scheduled annual tobacco tax increases.

- This study demonstrates evidence of cushioning of both regular indexation and large scheduled increases of tobacco excise in major tobacco retailers in Australia, with the price of factory-made cigarettes and roll-your-own tobacco products continuing to rise at least 1 month after the scheduled increase.

Contributors MS and MB designed the study. MB collated data, conceptualised and undertook the analysis and drafted the manuscript. All authors contributed to editing and finalisation of the manuscript.

Funding This research was supported by funding from the Cancer Council Victoria and by the Australian Prevention Partnership Centre through the NHMRC partnership centre grant scheme (Grant ID: GNT9100003) with the National Health and Medical Research Council (NHMRC), Australian Government Department of Health, ACT Health, Cancer Council Australia, NSW Ministry of Health, South Australian Department for Health and Well-being, Tasmanian Department of Health and VicHealth.

Competing interests None declared.

Patient consent for publication Not required.

Provenance and peer review Not commissioned; externally peer reviewed.

Open access This is an open access article distributed in accordance with the Creative Commons Attribution Non Commercial (CC BY-NC 4.0) license, which permits others to distribute, remix, adapt, build upon this work non-commercially, and license their derivative works on different terms, provided the original work is properly cited, appropriate credit is given, any changes made indicated, and the use is non-commercial. See: http://creativecommons.org/licenses/by-nc/4.0/.

\section{ORCID iDs}

Megan Bayly http://orcid.org/0000-0001-8072-783X

Michelle Scollo http://orcid.org/0000-0002-6583-4730

Melanie A Wakefield http://orcid.org/0000-0002-6183-5699

\section{REFERENCES}

1 World Health Organization. WHO report on the global tobacco epidemic: raising taxes on tobacco. Geneva: WHO, 2015.

2 Chaloupka FJ, Straif K, Leon ME. Effectiveness of Tax and price policies in tobacco control. Tob Control 2011;20 doi:10.1136/tc.2010.039982

3 Scollo M, Bayly M. 13.0 Introduction. In: Greenhalgh E, Scollo M, Winstanley M, eds. Tobacco in Australia: Facts \& issues. Melbourne: Cancer Council Victoria, 2020.

4 Explanatory Memorandum. Excise tariff Amendment (tobacco duty harmonisation) bill 2017, 2017.

5 Greenland SJ. The Australian experience following plain packaging: the impact on tobacco branding. Addiction 2016;111:2248-58.

6 Bayly M, Scollo M, White S, et al. Tobacco price boards as a promotional strategy-a longitudinal observational study in Australian retailers. Tob Control 2018;27:427-33.

7 Bayly M, Scollo MM, Wakefield MA. Who uses rollies? trends in product offerings, price and use of roll-your-own tobacco in Australia. Tob Control 2019;28:317-24.

8 Persoskie A, Donaldson EA, Ryant C. How tobacco companies have used package quantity for consumer targeting. Tob Control 2018. doi:10.1136/ tobaccocontrol-2017-053993. [Epub ahead of print: 31 May 2018].

9 van Schalkwyk MCl, McKee M, Been JV, et al. Size matters: an analysis of cigarette pack sizes across 23 European Union countries using Euromonitor data, 2006 to 2017. Plos One 2020;15:e0237513-e.

10 Bayly M, Scollo M. 10.5 Retailing of tobacco products in Australia. In: Bayly M, Scollo M, eds. Tobacco in Australia: Facts \& issues. Melbourne: Cancer Council Victoria, 2020.

11 Burton S, Williams K, Fry R, et al. Marketing cigarettes when all else is unavailable: evidence of discounting in price-sensitive neighbourhoods. Tob Control 2014;23:e24-9.

12 Scollo M, Bayly M, Wakefield M. The advertised price of cigarette packs in retail outlets across Australia before and after the implementation of plain packaging: a repeated measures observational study. Tob Control 2015;24:ii82-9.

13 Hiscock R, Branston JR, McNeill A, et al. Tobacco industry strategies undermine government Tax policy: evidence from commercial data. Tob Control 2018;27:488-97.

14 Hiscock R, Augustin NH, Branston JR, et al. Standardised packaging, minimum excise tax, and RYO focussed Tax rise implications for UK tobacco pricing. PLoS One 2020;15:e0228069.

15 Partos TR, Hiscock R, Gilmore AB. Impact of tobacco tax increases and industry pricing on smoking behaviours and inequalities: a mixed-methods study. In: Public health research. Southampton (UK: NIHR Journals Library, 2020: 8. 1-140.

16 Australian Taxation Office. Excise duty rates for tobacco. Canberra: ATO, 2019. https:// data.gov.au/data/dataset/excise-data

17 NSW Retail Tobacco Traders' Association. Australian retail Tobacconist. Australia: NSW Retail Tobacco Traders' Association, 2017-2019: 101-9.

18 Scollo M, Bayly M. 13.3 The price of tobacco products in Australia. In: Greenhalgh E, Scollo M, Winstanley M, eds. Tobacco in Australia: Facts \& issues. Melbourne: Cancer Council Victoria, 2020.

19 Chung F. Cigarettes to increase by \$2.70 a pack. newscomau, 2017.

20 Watts C, Burton S, Freeman B. 'The last line of marketing': covert tobacco marketing tactics as revealed by former tobacco industry employees. Glob Public Health 2020:1-14.

21 Gartner CE, Chapman SF, Hall WD, et al. Why we need tobacco sales data for good tobacco control. Med J Aust 2010;192:3-4.

22 Ministry of Health New Zealand. Tobacco returns, 2019. Available: http://www.health. govt.nz/our-work/preventative-health-wellness/tobacco-control/tobacco-returns 